\title{
Bone fragility and decline in stem cells in prematurely aging DNA repair deficient trichothiodystrophy mice
}

\author{
Karin E. M. Diderich • Claudia Nicolaije - Matthias Priemel • Jan H. Waarsing • \\ Judd S. Day • Renata M. C. Brandt • Arndt F. Schilling • Sander M. Botter • \\ Harrie Weinans • Gijsbertus T. J. van der Horst • Jan H. J. Hoeijmakers • \\ Johannes P. T. M. van Leeuwen
}

Received: 8 September 2010 /Accepted: 14 June 2011 /Published online: 4 August 2011

(C) The Author(s) 2011. This article is published with open access at Springerlink.com

\begin{abstract}
Trichothiodystrophy (TTD) is a rare, autosomal recessive nucleotide excision repair (NER) disorder caused by mutations in components of the dual functional NER/basal transcription factor TFIIH. TTD mice, carrying a patient-based point mutation in the $X p d$ gene, strikingly resemble many features of the human syndrome and exhibit signs of premature aging. To
\end{abstract}

K. Diderich, C. Nicolaije and M. Priemel contributed equally to this work.

K. E. M. Diderich • R. M. C. Brandt - S. M. Botter •

G. T. J. van der Horst $\cdot$ J. H. J. Hoeijmakers

MGC Department of Cell Biology and Genetics,

Center for Biomedical Genetics, Erasmus MC,

Rotterdam, The Netherlands

C. Nicolaije $\cdot$ S. M. Botter J. P. T. M. van Leeuwen $(\bowtie)$

Department of Internal Medicine, Erasmus MC,

Room Ee585, P.O Box 2040 CA, Rotterdam,

The Netherlands

e-mail: j.vanleeuwen@erasmusmc.nl

M. Priemel $\cdot$ A. F. Schilling

Center of Biomechanics and Skeletal Biology,

Department of Trauma Surgery,

University Medical Center Hamburg Eppendorf,

20246 Hamburg, Germany

J. H. Waarsing $\cdot$ J. S. Day $\cdot$ H. Weinans

Department of Orthopaedics, Erasmus MC,

3000 DR Rotterdam, The Netherlands

A. F. Schilling

Biomechanics Section, Hamburg University of Technology,

21073 Hamburg, Germany examine to which extent TTD mice resemble the normal process of aging, we thoroughly investigated the bone phenotype. Here, we show that female TTD mice exhibit accelerated bone aging from 39 weeks onwards as well as lack of periosteal apposition leading to reduced bone strength. Before 39 weeks have passed, bones of wild-type and TTD mice are identical excluding a developmental defect. Albeit that bone formation is decreased, osteoblasts in TTD mice retain bone-forming capacity as in vivo PTH treatment leads to increased cortical thickness. In vitro bone marrow cell cultures showed that TTD osteoprogenitors retain the capacity to differentiate into osteoblasts. However, after 13 weeks of age TTD females show decreased bone nodule formation. No increase in bone resorption or the number of osteoclasts was detected. In conclusion, TTD mice show premature bone aging, which is preceded by a decrease in mesenchymal stem cells/osteoprogenitors and a change in systemic factors, identifying DNA damage and repair as key determinants for bone fragility by influencing osteogenesis and bone metabolism.

Keywords DNA repair syndromes - Mouse models . Aging $\cdot$ Bone strength $\cdot$ Bone fragility .

Bone marrow stem cells

\section{Introduction}

Trichothiodystrophy (TTD) is a rare, autosomal recessive DNA repair disorder in which patients present an 
array of symptoms, including Photosensitivity, Ichthyosis, Brittle hair and nails (hallmark feature), Impaired intelligence, Decreased fertility, Short stature (hence, the acronym PIBIDS) and a severely reduced life span (Andressoo and Hoeijmakers 2005; Bootsma et al. 1998; Botta et al. 1998; Faghri et al. 2008; Itin et al. 2001). In addition, skeletal abnormalities, i.e., osteopenia in long bones and osteosclerosis in vertebrae, have been described (Chapman 1988; Civitelli et al. 1989; Itin et al. 2001; Kousseff and Esterly 1988; McCuaig et al. 1993; Price et al. 1980; Przedborski et al. 1990; Toelle et al. 2001; Wakeling et al. 2004). A significant proportion of TTD patients exhibit marked photosensitivity, due to impaired repair of UV-induced DNA lesions. Complementation analysis of UV-sensitive TTD patients revealed the involvement of three repair genes $(X P B, X P D$ and $T T D A$ ), encoding subunits of the dual functional DNA repair/basal transcription factor TFIIH (Giglia-Mari et al. 2004). This 10-subunit protein complex is involved in the nucleotide excision repair (NER) pathway, as well as in the initiation of transcription by RNA polymerases I and II (Chalut et al. 1994; Hashimoto and Egly 2009; Hoeijmakers et al. 1996; Hwang et al. 1996; Seroz et al. 1995; Svejstrup et al. 1996). NER consists of a complex 'cut-and-patch' type reaction involving $\sim 30$ proteins and is comprised of two sub-pathways, differing in the initial steps of DNA damage recognition (Gillet and Scharer 2006). Global genome NER removes a wide class of helix-distorting DNA damage (e.g., UV-induced photoproducts) from the overall genome (Sugasawa 2010). This pathway is primarily important for preventing DNA damageinduced mutations and thereby for preventing cancer. The second sub-pathway called transcription-coupled NER focuses on the preferential excision of lesions in the transcribed strand of active genes that actually block transcription elongation, to allow rapid resumption of arrested gene expression and thereby promoting cell survival after genotoxic stress (Hanawalt 2002; Hoeijmakers 2001). This sub-pathway is thought to counteract the cytotoxic consequences of DNA damage. TFIIH is as DNA helix opener implicated in both NER sub-pathways as well as in transcription initiation by promoter opening to allow the RNA polymerase to get hold of the transcribed strand for transcription elongation.

We have generated a mouse model in which we precisely mimicked a causative point mutation in the essential XPD gene of a TTD patient (TTD1BEL, mutation at the protein level $\mathrm{R}^{722} \mathrm{~W}$ ) (de Boer et al. 1998). TTD mice have a phenotype that strikingly resembles the symptoms of TTD patients and they were found to exhibit several premature aging-like features. Although TTD was not recognized as a segmental premature aging syndrome, some of the features observed in the mouse model were also incidentally reported in patients: deterioration of renal, liver and heart tissues, lymphoid depletion, reduced hypodermal fat, aortic sarcopenia, skeletal abnormalities and a (in patients strongly, in mice moderately) reduced life span (Chapman 1988; Civitelli et al. 1989; de Boer et al. 2002; Kousseff and Esterly 1988; Leupold 1979; McCuaig et al. 1993; Price et al. 1980; Przedborski et al. 1990; Toelle et al. 2001; Wakeling et al. 2004; Wijnhoven et al. 2005). Concerning skeletal aging, Price and co-workers reported a patient who at the age of 7 years showed decreased bone density in the distal bones on roentgenographic examination (Price et al. 1980). Chapman reported a 5-year-old child who exhibited decreased bone density in the distal limbs and osteopenia in the most distal parts (Chapman 1988).

Recent studies suggest that aging and the associated increase in reactive oxygen species (ROS) may account for the increased bone resorption associated with the acute loss of estrogens or androgens rather than estrogen deficiency per se (Manolagas 2010 and references therein). Loss of these hormones decreases defence against oxidative stress in bone while ROS greatly influence the generation and survival of osteoclasts, osteoblasts, and osteocytes (Manolagas 2010 and references therein). Forkhead box O (FoxO) transcription factors defend against oxidative stress by activating genes involved in free radical scavenging and apoptosis. Recently, it was shown that loss of FoxO transcription factors leads to an increase in oxidative stress and consequently osteoblast apoptosis with an osteoporotic phenotype characterized by decreased bone mass at both cancellous and cortical sites as a result (Ambrogini et al. 2010) and specifically deletion of FoxO1 in osteoblasts decreased osteoblast numbers, bone formation rate, and bone volume (Rached et al. 2010).

Thus, the TTD mouse could be a model for bone fragility, which is observed in both aging women and men. Whereas postmenopausal women show an accelerated loss of predominantly trabecular bone, 
due to increased number and activity of osteoclasts, in bone fragility both women and men show a slow continuous phase of decrease in bone mass in which the density of trabecular bone reduces and cortical bone thins (Chan and Duque 2002; Harada and Rodan 2003; Kawaguchi et al. 1999; Riggs et al. 2002; Seeman 2002). This is partly counteracted by increased periosteal apposition (Seeman 2001), i.e., bone formation on the outside of the bone (periosteum), a critical process that continues throughout life (Riggs et al. 2002; Seeman 2002, 2003a). Periosteal apposition is thought to be a response to the loss of trabecular bone as well as endosteal resorption and aims to maintain bone strength by increasing the bone perimeter (Russo et al. 2006). The mechanisms underlying these age-related changes are poorly understood.

To assess the contribution of deficiencies in DNA repair/basal transcription in skeletal aging and to determine to which extent the progeroid features in the mouse and human disorder truly reflect bona fide aging, we decided to thoroughly examine the skeletal aging as this process has been amply characterized in normal aging. The TTD mouse model may provide a unique tool to study aging and bone metabolism and to assess the impact of DNA repair on skeletal aging.

\section{Materials and methods}

Mice and bones

The cohort of wild-type and TTD mice included eight female animals per age group per genotype. Mice were sacrificed at 13-week intervals up to an age of 104 and 78 weeks for wild-type and TTD mice, respectively. All mice were on a C57BL/6J background, maintained on a 12:12 h light-dark cycle and fed ad libitum with 'rat and mouse breeder and grower diet' from Special Diet's Services (minimal $0.5 \% \mathrm{Ca}$ and $0.3 \% \mathrm{Pi}$ ). The animals were injected intraperitoneal with calcein $(10 \mu \mathrm{g} / \mathrm{g}$ body weight) 10 and 3 days before sacrifice in order to study the bone formation occurring in 1 week. After anaesthetization with isoflurane, blood was collected by an orbital puncture; subsequently the mice were killed by cervical dislocation. Femurs and tibiae were isolated and were either used immediately for bone marrow isolation, snap frozen in liquid nitrogen and stored at $-80^{\circ} \mathrm{C}$ or fixed in Burkhardt, which was replaced by $70 \%$ ethanol after 3 days. There was no significant difference in bone length between wildtype and TTD mice (data not shown). As required by Dutch law, formal permission to generate and use genetically modified animals was obtained from the responsible local and national authorities. All animal studies were approved by an independent Animal Ethics Committee (Dutch equivalent of the IACUC).

Micro-computed tomography

Fixed tibiae from wild-type and TTD mice of different ages ( $n=4-6$ per group) were scanned by micro-computed tomography $(\mu \mathrm{CT})$ from proximal end to mid-diaphysis using the SkyScan 1072 microtomograph (SkyScan, Antwerp, Belgium) with a voxel size of $8.82 \mu \mathrm{m}$. The reconstructed data sets were segmented using an automated algorithm based on local thresholds (Waarsing et al. 2004). Three-dimensional (3D) morphometric analysis of the bone was performed using subsequent software packages, including Nrecon, CT-analyze and Dataviewer (http://www.skyscan.be/ products/downloads.htm) and freely available software of the 3D-Calculator project (http://www.erasmusmc. nl/orthopaedie/research/labor/downloads). For all mice a standardized metaphyseal-diaphyseal area (3.7$6.9 \mathrm{~mm}$ from the proximal end; mainly consisting of cortical bone) and a metaphyseal area (100 sections starting 30 sections below our offset landmark within the epiphyseal growth plate; including more trabecular bone) were selected for analysis. It was previously shown that murine femur length does not increase after 26 weeks of age (Glatt et al. 2007). We determined the following parameters: cortical bone volume, 3D thickness distribution (Hildebrand et al. 1999), cortical thickness, periosteal perimeter, endocortical volume, trabecular bone volume fraction (BV/TV), trabecular number and trabecular thickness. Polar moment of inertia (measure of the geometrical distribution and a proxy for mechanical stiffness and strength per transverse cross-section) was determined to analyze the consequence of differences in geometry. The 3D thickness distribution graph is similar to a usual frequency distribution, only with infinitely small bins. It is a continuous equivalent, similar to a probability density distribution in statistics. While with discrete bins the $y$-axis would show volume (fraction), this continuous case narrows it down to volume density (volume $/ \mu \mathrm{m}$ ). 
Histomorphometric analysis

To assess the dynamic histomorphometric indices, mice received intraperitoneal injections with calcein 10 and 3 days prior to sacrifice. One tibia of each mouse was dehydrated in ascending alcohol concentrations and embedded in polymethylmetacrylate (PMMA) as described previously (Amling et al. 1999). Sections of $5 \mu \mathrm{m}$ were cut in the sagittal plane defined by the frontal aspect of the tibia and the fibula on a Microtec rotation microtome (Techno-Med, Munich, Germany). Consecutive serial sections are cut in this plane and the section with the widest diameter is used for analysis, thereby minimizing potential artifacts. Subsequently, the sections were stained by toluidine blue, van Gieson/von Kossa and Giemsa procedures as described (Amling et al. 1999).

Parameters of static and dynamic histomorphometry were quantified on these undecalcified proximal tibia sections. For each animal, the bone formation rate was determined by fluorochrome (calcein) measurements using two non-consecutive $12-\mu \mathrm{m}$ sections per animal.

Analysis of osteocyte number per bone area (per square millimeter), osteoblast number per bone perimeter (per millimeter), osteoclast number per bone perimeter (per millimeter), osteoid volume per bone volume (percentage), osteoid surface per bone surface (percentage) was carried out according to standardized protocols (Parfitt et al. 1987) using the OsteoMeasure histomorphometry system (Osteometrics Inc., Atlanta, GA, USA).

\section{Mechanical testing}

Defrosted femurs from 13-, 26-, 52- and 78-weekold wild-type and TTD females as well as from 104-week-old wild-type females (5-8 mice/group) were excised from the soft tissues. Femurs were tested in a three-point bending assay using a Lloyd LRX mechanical test frame, constructed with $3 \mathrm{~mm}$ hemi-cylindrical supports with a 9-mm total span. The femurs were aligned such that the neutral axis was parallel to the sagittal plane (i.e., the femoral head was in the horizontal plane and the posterior aspect of the condyles were facing down). The lesser trochanter was used as a reference point and aligned with one of the two supports. All samples were preconditioned for 5 cycles to $2 \mathrm{~N}$ at a rate of
$0.01 \mathrm{~mm} / \mathrm{s}$ before testing to failure at a rate of $0.02 \mathrm{~mm} / \mathrm{s}$.

Backscatter scanning electron microscopy

Processing and analyses were done as described previously (Broderick et al. 2005). In short, from each group (i.e., 26-, 52- and 78-week-old wild-type and TTD mice) the distal halves of the femurs used for mechanical testing were embedded in blocks of MMA, such that each block contained one distal femur from each genotype and age group. Within a block, all femurs were placed within a plane, such that the longitudinal lateral-medial plane of the femurs coincided with the plane of embedding. Embedding several samples in one block enabled us to image these samples within one scanning electron microscopy (SEM) session, thus decreasing the variance in the measurements.

After embedding, the blocks were cut in two on an electric band saw (Exakt, Norderstedt, Germany), resulting in a slab of plastic with two parallel surfaces, parallel to the plane of embedding of the femurs. Starting from the posterior side of the bones, material was removed using an automatic grinding system (Buehler Phoenix 4000) with p400 grid paper until an interior surface, halfway between the ventral and dorsal external surfaces, was exposed. To reduce the roughness of the surface the blocks were ground with p1200 paper followed by polishing using $3 \mu \mathrm{m}$ diamond paste with polishing paper (Buehler Texmet 1000). The resulting surface had a roughness $\left(R_{\mathrm{a}}\right)$ smaller than $0.05 \mu \mathrm{m}$. The blocks were cleaned, sonicated and sputter coated with a thin layer of carbon (Bio-Rad Temcarb Carbon Coater, Bio-Rad Microscience Division) to enable conduction of the electron beam to the sample surface.

Backscatter SEM images were taken of trabecular bone of the metaphyseal and epiphyseal regions of each bone sample, and of the cortex using methods described in detail previously (Broderick et al. 2005). The images were taken at an accelerating voltage of $25 \mathrm{kV}$, a working distance of $17 \mathrm{~mm}$ and $50 \times$ magnification. Before and after imaging calibration images were taken of an aluminum standard embedded in each block and of the MMA material. The equivalent $Z$ value (atomic number) of the MMA was obtained by calibration with aluminum $(Z=13)$ and carbon $(Z=6)$ standards (Micro Analysis Consultants). 
From each image, the histogram of equivalent $Z$ values was calculated of which the mean value represented the mean mineralization of the bone tissue (Roschger et al. 1998).

Tartrate-resistant acid phosphatase assay

Bone resorption was determined by measuring serum tartrate-resistant acid phosphatase (TRAP) levels using the TRAP assay purchased from SBA Sciences (Turku, Finland).

Bone marrow isolation, cell culture and cell culture staining

Bone marrow was collected by spinning down the bone marrow into an Eppendorf tube at 5,000 rev/min for 2 min immediately after obtaining the bones from the mice. Erythrocytes were lysed using erylysis buffer (1.55 $\mathrm{M} \mathrm{NH}_{4} \mathrm{Cl}, 0.1 \mathrm{M} \mathrm{KHCO}_{3}, 1 \mathrm{mM}$ EDTA $\left.(10 \times)\right)$ and cells were washed and seeded at 1,000,000 cells/ well (12 wells) for osteoblasts, 100,000 cells/well (96 wells) for osteoclasts and 750,000 cells/well, for adipocytes (24 wells). For osteoblast cultures the cells were cultured in phenol-red free $\alpha$-minimal essential medium (Gibco BRL), supplemented with 100 units $/ \mathrm{ml}$ penicillin, $100 \mu \mathrm{g} / \mathrm{ml}$ streptomycin (Life Technologies, Breda, the Netherlands), $250 \mathrm{ng} / \mathrm{ml}$ amphotericin B (Sigma), $20 \mathrm{mM}$ Hepes, $1.8 \mathrm{mM} \mathrm{CaCl}_{2}$, and $15 \%$ ( $\left.\mathrm{vol} / \mathrm{vol}\right)$ heat-inactivated FCS (Gibco BRL), pH 7.5. From day 3 onward, the culture medium was supplemented with $50 \mu \mathrm{M}$ vitamin C (Sigma) and $10 \mathrm{mM} \beta$-glycerophosphate (Sigma). At days 14 and 21 of culture, cells were fixed in $70 \%$ ethanol and stained for alkaline phosphatase (ALP) and alizarin red, respectively. For ALP staining, cells were incubated in Tris-HCL (pH 9.5) containing $50 \mathrm{mM} \mathrm{MgCl} 2,0.6 \mathrm{mg} / \mathrm{ml}$ bromo-chloro-indoryl phosphate (Sigma), and $150 \mu \mathrm{g} / \mathrm{ml}$ nitro blue tetrazolium (Sigma) for 20 min and washed with PBS. Alizarin red staining was performed, incubating the cells for $10 \mathrm{~min}$ in a saturated alizarin red $\mathrm{S}$ solution in distilled water ( $\mathrm{pH}$ 4.2), after which the cells were washed with distilled water. Osteoblast colony-forming potential and mineralisation potential were determined as previously described after 14 and 21 days, respectively, of culture (van der Eerden et al. 2005). Colonies were counted by eye, plates were scanned and colony surface area was determined by computer analysis (Bioquant software). Alizarin Red staining was quantified after extraction and measured at $405 \mathrm{~nm}$ on a plate reader.

Osteoclasts were cultured as previously described (van der Eerden et al. 2005). Shortly, cells were cultured for 6 days in the presence of $30 \mathrm{ng} / \mathrm{ml}$ recombinant M-CSF (R\&D Systems) and $20 \mathrm{ng} / \mathrm{ml}$ recombinant murine RANKL-TEC (R\&D Systems), and the media were refreshed at day 3 . At the end of the human and murine cultures, cells were washed with PBS, fixed in PBS-buffered paraformaldehyde $(4 \% \mathrm{vol} / \mathrm{vol})$ or formalin $(10 \% \mathrm{vol} / \mathrm{vol})$, respectively, and stored at $4^{\circ} \mathrm{C}$ for TRAP staining and immunocytochemistry. Bone resorption was analyzed using the resorption pit assay. Osteoclasts were cultured on bovine cortical bone slices, after 6 days of culture the cells were lysed in water and the bone slices were sonicated in $10 \%$ (vol/vol) ammonia (Merck) for $10 \mathrm{~min}$. After extensive washing, the cells were incubated in filtered potassium aluminum sulfate (Sigma) for $10 \mathrm{~min}$ and subsequently stained with filtered Coomassie brilliant blue (Phastgel Blue R; Amersham Pharmacia Biotech) for $5 \mathrm{~s}$. Osteoclast number and resorption capacity were determined as previously described (van der Eerden et al. 2005) and analyzed using freely available Image $\mathrm{J}$ software (version 1.41; http://rsbweb.nih.gov/ij/).

Adipocytes were cultured on adipogenic (DMEM [Gibco, Paisley, UK] supplemented with $\mathrm{P} / \mathrm{S}$, amphotericin B [250 ng/ml, Sigma] and 15\% heat-inactivated FCS [Gibco]) medium. Adipogenesis was induced after a 3-week expansion phase by adding insulin $(0.1 \mu \mathrm{g} / \mathrm{ml}$, Sigma), indomethacin (1 mM, Sigma) and dexamethasone $\left(1 \times 10^{-7} \mathrm{M}\right.$, Sigma) for 2 weeks.

Adipocyte cultures were fixated $\mathrm{O} / \mathrm{N}$ with $10 \%$ formaline, washed with $60 \% \mathrm{IPOH}$ and stained with Oil-Red O solution (60:40 dilution of Oil-Red O stock solution (Clin-Tech limited) in $\mathrm{H}_{2} \mathrm{O}$ ) after which the total amount of adipocytes per well was determined.

\section{PTH treatment}

Twenty TTD females were weighed at the age of 45 weeks and randomly divided into two groups $(n=10$ per group): (1) subcutaneous injection with human parathyroid hormone(1-34) (Bachem, Germany) (40 $\mu \mathrm{g} / \mathrm{kg}$ body weight) in a weekly alternating regimen (PTH); (2) subcutaneous injection with phosphate- 
buffered saline in a weekly alternating regimen (VEH). Animals were weighed at the start of every injection week. At 65 weeks of age, animals were sacrificed and femurs were prepared for $\mu \mathrm{CT}$ scanning.

\section{Statistics}

Micro-CT parameters, histomorphometric data, femur length, ultimate load, bone resorption and mineralization data and parameters of cell culture analyses were compared between the age groups (significance compared to 13 or 26 weeks of age) of both genotypes separately using one-way ANOVAs with Tukey posthoc test (Graph Pad InStat version 3.05: Graph Pad Software, San Diego, CA, USA; www.graphpad.com). In addition, the micro-CT parameters, histomorphometric data, femur length, ultimate load, bone resorption data, and parameters of cell culture analyses were compared between genotypes for all age groups separately using two-tailed unpaired $t$-tests.

\section{Results}

To study the bone phenotype in normal and premature aging female TTD mice, we performed a systematic cohort study including eight mice per age group per genotype. A previous study, performed on a hybrid C57BL/6J 129ola genetic background, showed that TTD mice live shorter than wild-type mice (de Boer et al. 2002). In the present study, we were able to analyse 13-, 26-, 39-, 52-, 65- and 78-week-old wild-type and TTD mice in a homogeneous $\mathrm{C} 57 \mathrm{Bl} / 6$ genetic background. For wild-type control mice, we could in addition analyse 91- and 104-week-old mice.

\section{Bone geometry}

First, 3D thickness distribution was analyzed using $\mu \mathrm{CT}$. In tibiae from wild-type mice, a gradual progressive decline in $3 \mathrm{D}$ thickness distribution was observed with age (Fig. 1a). In TTD mice, this process was accelerated with a severe decrease in 3D thickness distribution after 39 weeks of age (Fig. 1b). Already at 52 weeks of age, 3D thickness distribution in TTD tibiae reached a level that in wildtype mice was only reached at 91 weeks of age (Fig. 1c). Thus age-related decrease in bone mass occurred earlier in TTD mice than in wild-type mice.
To study this difference in onset of decrease in bone mass in more detail, we analyzed specific $\mu \mathrm{CT}$ parameters. In wild-type mice, cortical bone volume gradually decreased with age, only reaching significance at 104 weeks of age at which time a $12 \%$ decrease in bone volume compared to 26-week-old wild-type bones was observed (Fig. 1d). At 26 and 39 weeks of age, tibiae of TTD mice had a bone volume similar to that of wild-type mice (Fig. 1d). However, in the period thereafter, bone volume rapidly decreased to 31\% (78-week-old TTD mice dropping to $69 \%$ of the bone volume of 26 -week-old TTD mice), which was significantly lower than the $9 \%$ decline in age-matched wild-type mice at 78 weeks of age (Fig. 1d). Already at 52 weeks of age TTD mice reached a cortical bone volume comparable to that of 104-week-old wild-type mice (Fig. 1d). In line with cortical bone volume, wild-type tibiae maintained their cortical thickness up to 78 weeks of age and showed a decrease thereafter while TTD tibiae already displayed a rapid drop in cortical thickness after 39 weeks of age resulting in a significantly thinner cortex in TTD mice (Fig. 1e).

Next, we analyzed the bone perimeter. As depicted in Fig. 1f, tibiae from young mice had a similar perimeter (at 26 weeks: $5.80 \mathrm{~mm}$ in wild-type mice and $5.96 \mathrm{~mm}$ in TTD mice), again indicating normal bone development in TTD mice. From 52 weeks onwards, wild-type tibiae showed a progressive increase in perimeter reaching $6,33 \mathrm{~mm}$ at 78 weeks (9\% increase) and $6.78 \mathrm{~mm}$ at 104 weeks $(17 \%$ increase). In contrast, TTD mice failed to show an increase in perimeter $(5.88 \mathrm{~mm}$ at 78 weeks). In 78 week-old wild-type mice, the perimeter is significantly higher compared to TTD mice (Fig. 1f). Thus, TTD mice lack the age-related increase in perimeter as seen in wild-type tibiae (Fig. 1f).

The endocortical volume was larger in TTD than in wild-type mice in the early phase of life but later in life endocortical volume in wild-type mice increased and becomes equal to that of TTD mice (Fig. 1g). The temporal dynamics in endocortical volume in wild-type mice, showing an increase after 52 weeks, match that observed for perimeter, showing an increase from 52 weeks of age onwards. However, periosteal apposition could no longer match the endocortical bone loss in wild-type mice after 78 weeks of age leading to a decrease in cortical thickness (Fig. 1e). 

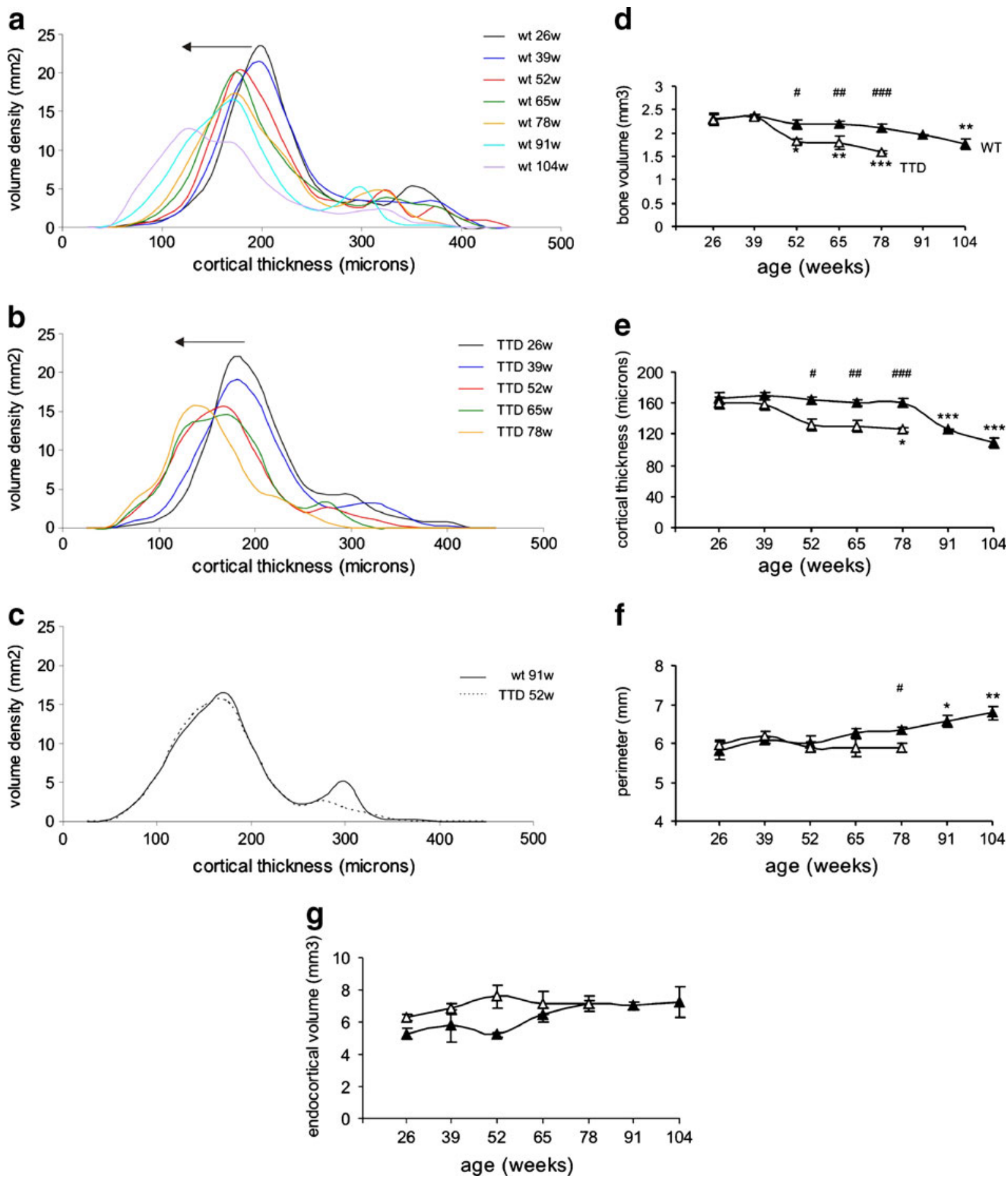

Fig. 1 Thickness distribution and cortical bone parameters in wild-type and TTD mice. Cortical thickness distribution in aging wild-type (a) and TTD mice (b) with the arrow indicating the direction of change with aging. Comparison of thickness distribution in 52-week-old TTD mice (dotted line) compared to 91-week-old wild-type mice (solid line) (c). Bone parameters in aging wild-type mice (solid triangles) and TTD mice (open triangles): cortical bone volume (d), cortical thickness (e), perimeter (f) and endocortical volume (g). TTD mice compared

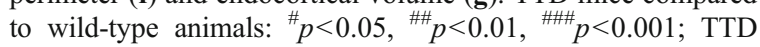
mice and wild-type animals compared to their 26-week time point: ${ }^{*} p<0.05,{ }^{* *} p<0.01,{ }^{* * *} p<0.001$; error bars represent SEM 
Next, we analyzed trabeculae in the metaphyseal area. Aging wild-type mice showed a gradual decrease in both BV/TV and trabecular number (Fig. 2a and b) while trabecular thickness showed a mild increase with aging (Fig. 2c). Overall, no significant differences between wild-type and TTD mice were observed. In contrast to wild-type mice, the trabecular bone in TTD
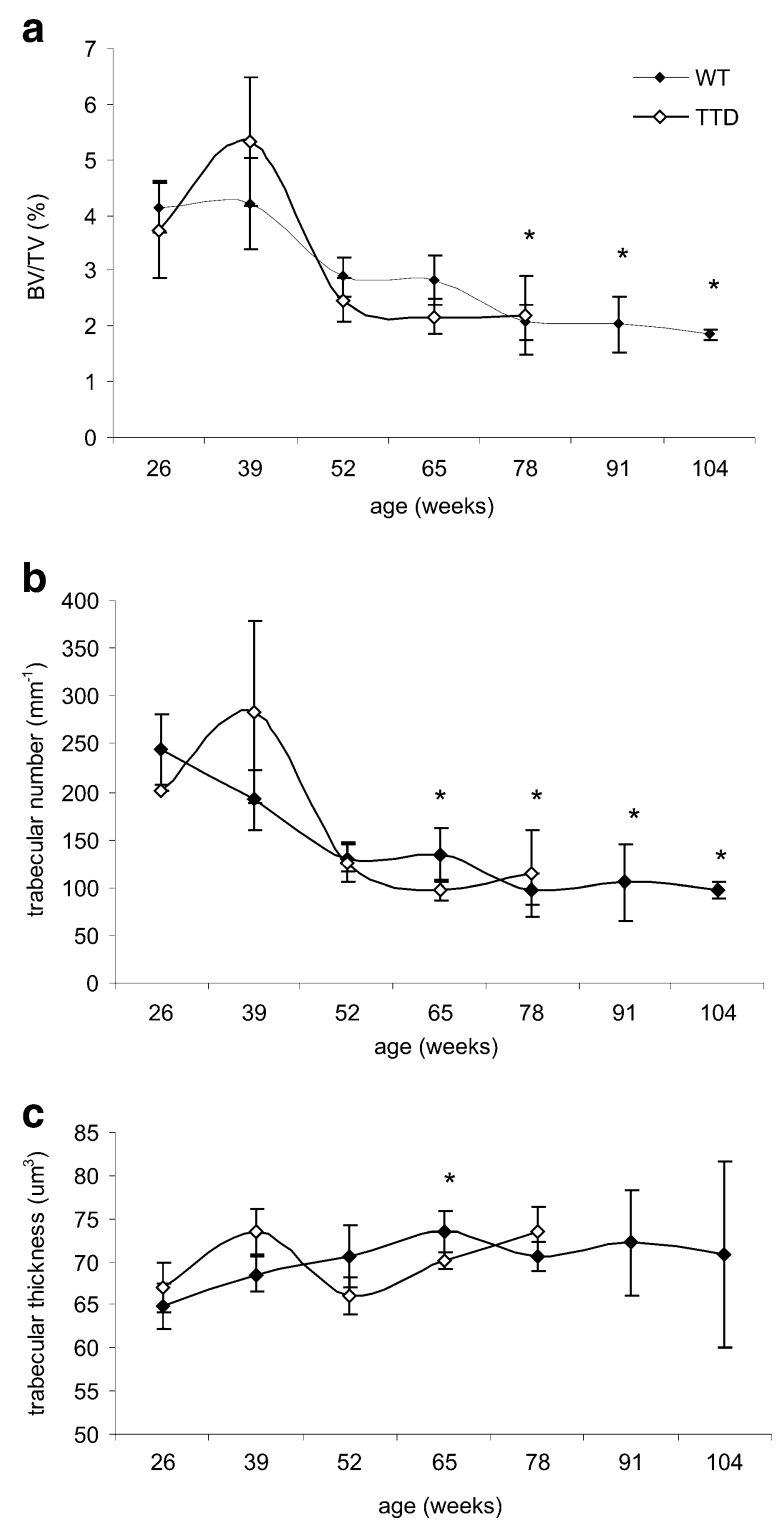

Fig. 2 Trabecular bone parameters in wild-type and TTD mice. Bone parameters measured in 100 cross-sections in the metaphysis of aging wild-type mice (solid triangles) and TTD mice (open triangles): a trabecular bone volume fraction (BV/ TV), b trabecular number and c trabecular thickness. Wild-type animals compared to their 26 -week time point: $* p<0.05$; error bars represent SEM mice showed a remarkable dynamic pattern around 39 weeks of age as exemplified by a transient nonsignificant increase in BV/TV, trabecular number and trabecular thickness (Fig. 2a, b and c).

Histomorphometric analysis

In order to analyze the lack of periosteal expansion in TTD mice in more detail, we examined endosteal and periosteal bone apposition by double labeling studies. In wild-type mice both periosteal and endosteal bone formation were present throughout life (Fig. 3a). In contrast, in TTD mice endosteal apposition was present whereas periosteal apposition was virtually absent in older TTD mice (Fig. 3a). Quantitative analyses revealed no significant difference in endosteal bone formation between 13-week-old wild-type and TTD mice (Fig. 3b). At 39 weeks of age, endosteal bone formation was significantly decreased in TTD mice compared to wild-type mice, but after 39 weeks of age endosteal bone formation decreased in wild-type mice as well (Fig. 3b). At 78 weeks of age, wild-type and TTD mice showed a $20-25 \%$ decrease in endosteal bone formation when compared to 13-week-old animals. At 13 weeks of age, periosteal apposition showed no significant difference between wild-type and TTD mice (Fig. 3c). However, after 13 weeks of age, TTD mice showed a dramatic and significant decrease in periosteal apposition compared to wild-type mice (Fig. 3c). Only at 78 weeks of age, when periosteal apposition in wild-type mice decreased as well, there was no significant difference compared to TTD mice anymore (Fig. 3c). At that time, however, TTD mice exhibited a $60 \%$ decrease in periosteal apposition compared to a $25 \%$ decrease in wild-type mice when compared to 13-week-old animals. Osteocytes in cortical sections of tibiae of wild-type and TTD mice were measured to assess whether a reduced number of osteocytes in TTD mice could play a role in impaired periosteal apposition. However, no significant difference in the number of osteocytes was found between wild-type and TTD mice or in aging animals (data not shown). In addition, we analyzed the number of osteoblasts, osteoclasts and osteoid volume. The number of osteoblasts did not show a significant difference between wild-type and TTD tibiae at the analyzed ages (Fig. 3d). However, there was a significance difference in number of osteoblasts over life ( $p=0.03$, KruskalWallis test). No significant difference in the number of 


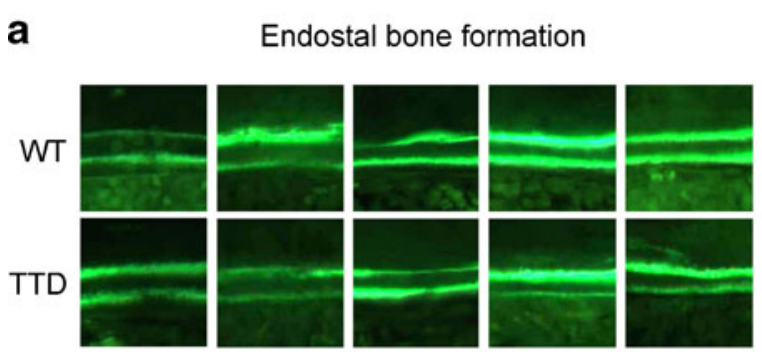

Periostal bone formation

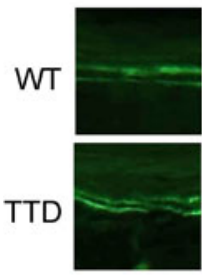

13 wks

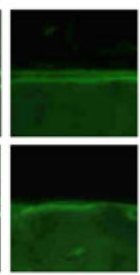

39 wks

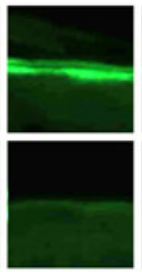

52 wks

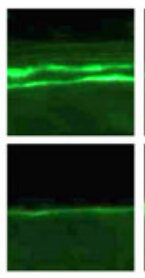

65 wks

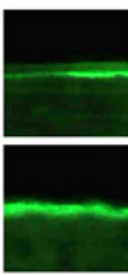

78 wks

b

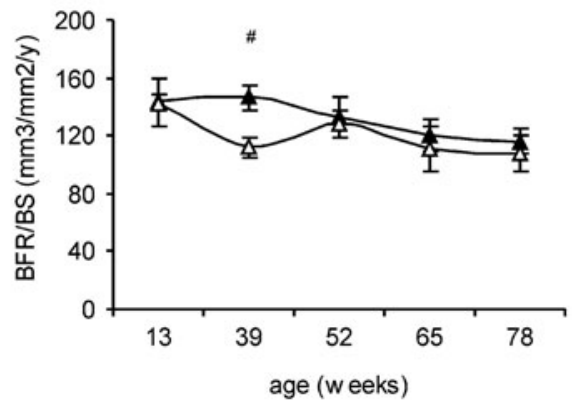

C

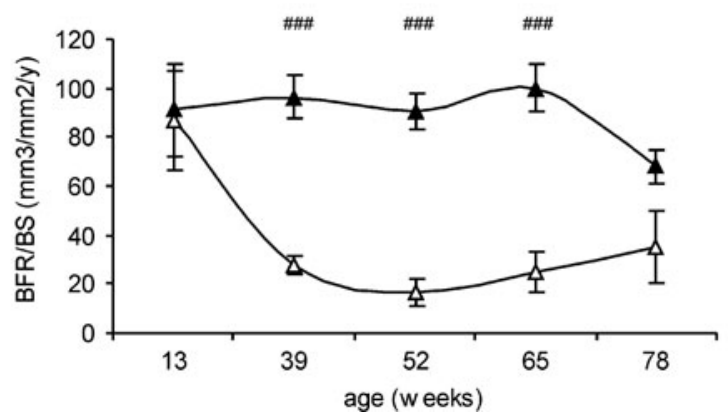

Fig. 3 Histomorphometric analysis and backscatter scanning electron microscopy of wild-type and TTD mice. Calcein double labeling of endosteal and periosteal bone formation in wild-type and TTD mice (a). Quantified endosteal apposition (b), quantified periosteal apposition (c), number of osteoblasts (d), number
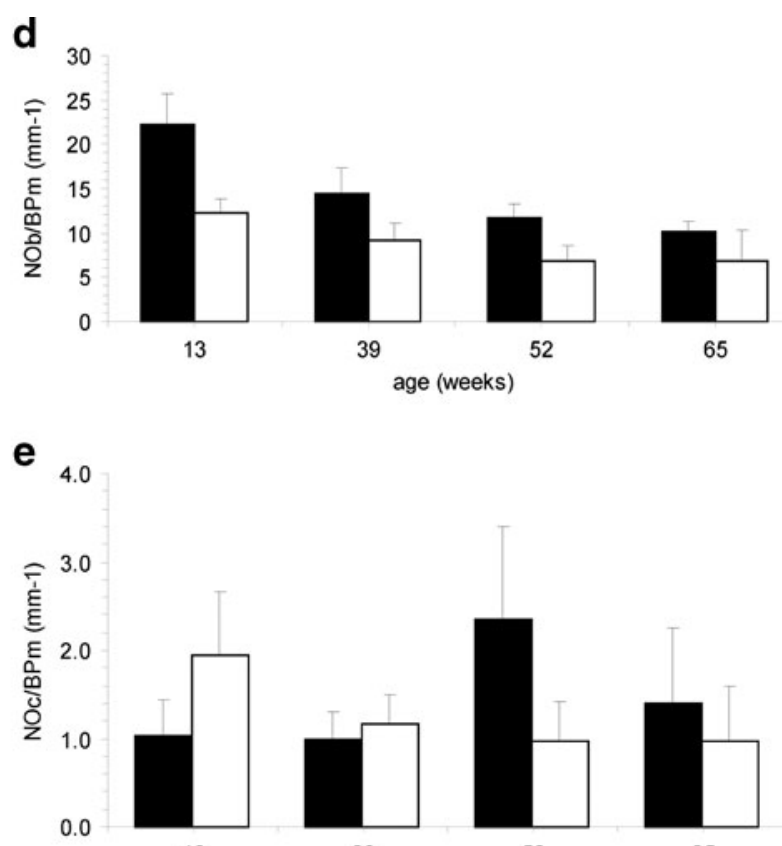

13
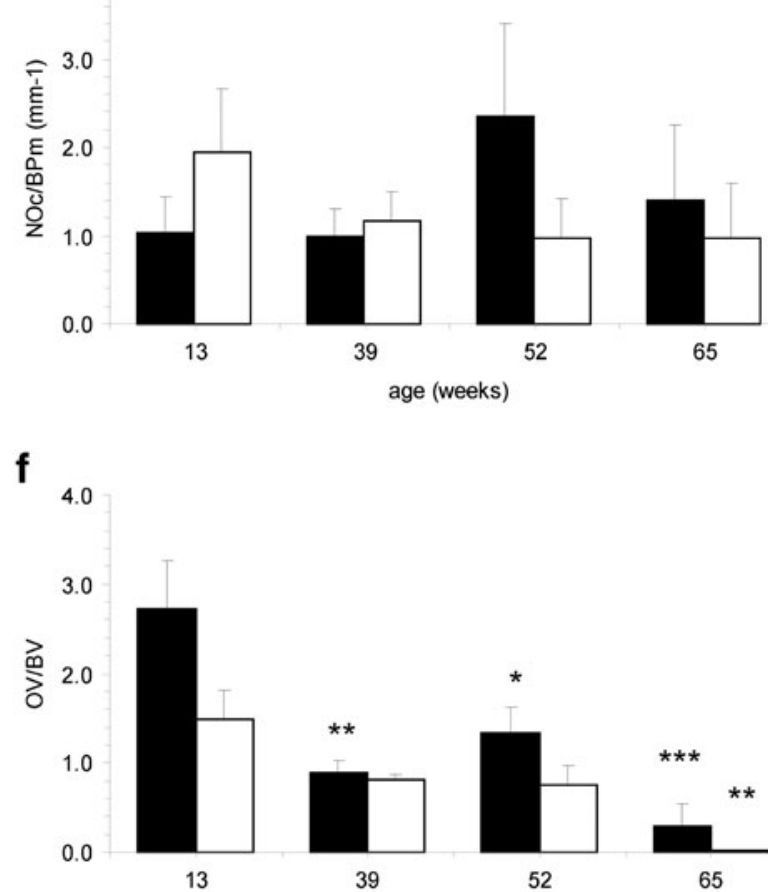

65

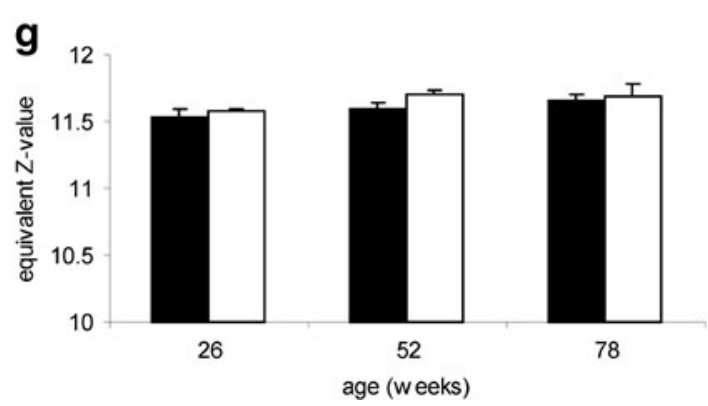

of osteoclasts (e) and osteoid volume (f) and mineralization status (g) in wild-type (solid symbols) and TTD (open symbols) mice. TTD mice compared to wild-type mice: ${ }_{p} p<0.05,{ }^{\# \#} p<$ 0.001 ; TTD mice compared to their 13 -week time point: ${ }^{*} p<$ $0.05, * * p<0.01, * * * p<0.001$; error bars represent SEM 
osteoclasts was observed between wild-type and TTD mice or in aging animals (Fig. 3e). Osteoid volume seemed to decrease with age in both wild-type and TTD tibiae, but at none of the ages osteoid volume was significantly different between wild-type and TTD mice (Fig. 3f). Osteoid surface showed similar results (data not shown). These osteoid data exclude that the differences observed by $\mu \mathrm{CT}$ are due to a mineralization defect. This is further supported by quantitative backscatter scanning electron microscopy showing no significant differences in degree of mineralization (Fig. 3g).

Mechanical testing of bone strength

The overall picture that emerges is that compared to wild-type mice, aging TTD mice show an accelerated decrease in bone mass, which initiated between weeks 39 and 52, and that TTD mice lack the age-related increase in perimeter. To analyze the consequence of these geometric changes, we calculated the polar moment of inertia, which is a measure of the geometrical distribution and a proxy for mechanical stiffness and strength per transversal cross-section. This demonstrated that tibiae from wild-type mice maintained polar moment of inertia at a constant level throughout life, even at 91 and 104 weeks of age when bone volume and cortical thickness were reduced (Fig. 4a). In contrast, TTD tibiae failed to maintain the polar moment of inertia and even showed a progressive decrease throughout life starting at 39 weeks of age (Fig. 4a), i.e., 78-week-old TTD mice showed a $65 \%$ decrease in moment of inertia compared to 39-week-old TTD mice whereas the moment of inertia in 78-week-old wildtype mice showed a $106 \%$ increase compared to 39 week-old wild-type mice.

Using a three-point bending assay, we tested whether the differences in polar moment of inertia and lack of periosteal apposition in TTD mice resulted in a difference in bone strength. Femurs from wild-type and TTD mice showed a comparable and increasing ultimate fracture load up to 26 weeks of age (Fig. 4b). After 26 weeks there was a progressive decrease in ultimate fracture load in both genotypes but this was clearly more prominent and significant in TTD mice showing a $50 \%$ decline compared to a $25 \%$ decline in wild-type mice (Fig. 4b). Femurs of TTD mice fractured at a lower ultimate load than femurs of wild-type mice, which reached significance in 52- and 78-week-old animals.
Bone resorption

In wild-type and TTD mice, the levels of TRAP were measured to assess whether differences in bone resorption could explain the observed morphometric differences. As expected, bone resorption seemed to increase with aging in both wild-type and TTD mice (Fig. 4c). In addition, TTD seemed to have higher levels of TRAP. However, no significant differences were observed between genotypes or with age.
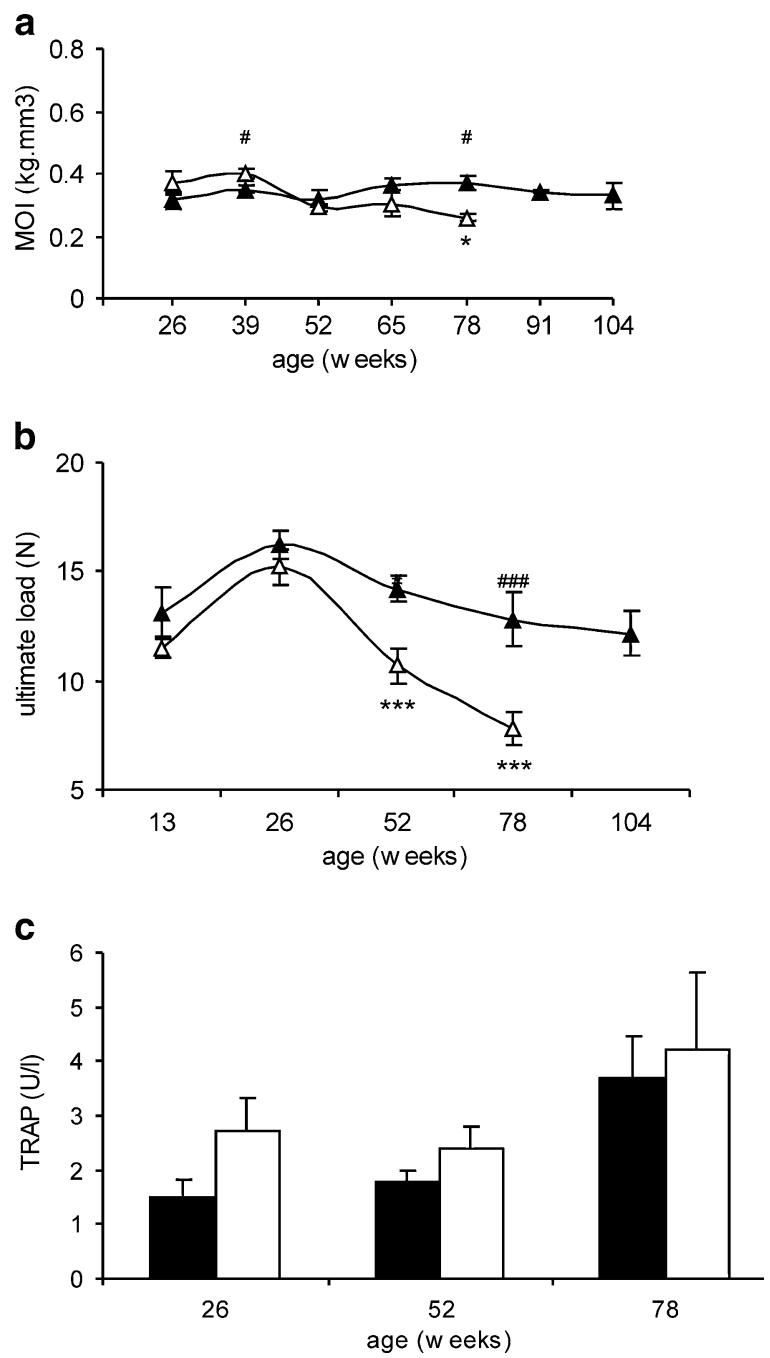

Fig. 4 Mechanical testing and TRAP assay in wild-type and TTD mice. Polar moment of inertia in tibiae (a), ultimate load applied on femurs (b), serum TRAP levels (c), of wild-type (solid symbols) and TTD (open symbols) mice. TTD mice compared to wild-type animals: ${ }^{\#} p<0.05,{ }^{\# \#} p<0.001$; TTD and wild-type mice compared to their 26 -week time point: ${ }^{*} p<0.05$, $* * * p<0.001$; error bars represent SEM 


\section{Bone marrow cell cultures}

To assess whether the differences in bone phenotype in TTD mice are due to an impaired osteoblast and/or osteoclast differentiation, we performed bone marrow cultures and assessed the capacity to form osteoblasts and adipocytes from mesenchymal stem cells as well as osteoclasts from hematopoietic stem cells for wildtype and TTD mice of various ages. The number of TRAP-positive osteoclasts was similar in 13-week-old wild-type and TTD cultures (Fig. 5a). In the following period, wild-type, but not TTD, mice showed a significant decline in the number of osteoclasts resulting in a significant higher number of osteoclasts at 26 weeks of age in TTD mice. At later ages the number of osteoclasts was similar in wild-type and TTD mice (Fig. 5a). The amount of resorption by mature osteoclasts was not significantly different between wild-type and TTD mice (Fig. 5b). At 13 weeks of age, the number of bone nodules was similar for wild-type and TTD mice (Fig. 5c). However, the number of bone nodules in TTD mice showed a rapid decline resulting in significantly lower numbers of bone nodules at 26 and 39 weeks of age compared to wild-type mice (Fig. 5c). Subsequently, the number of bone nodules in wild-type mice also

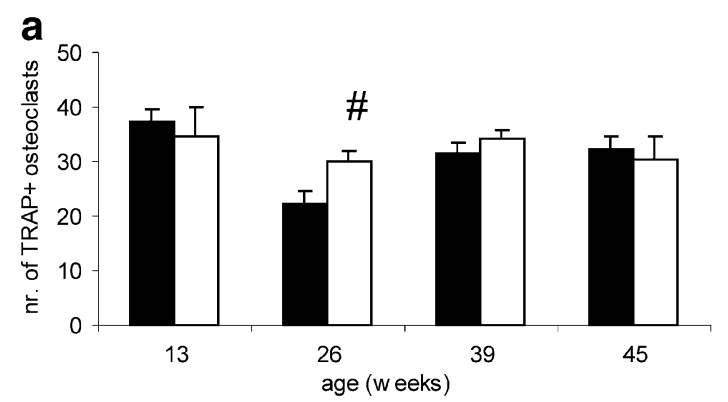

b
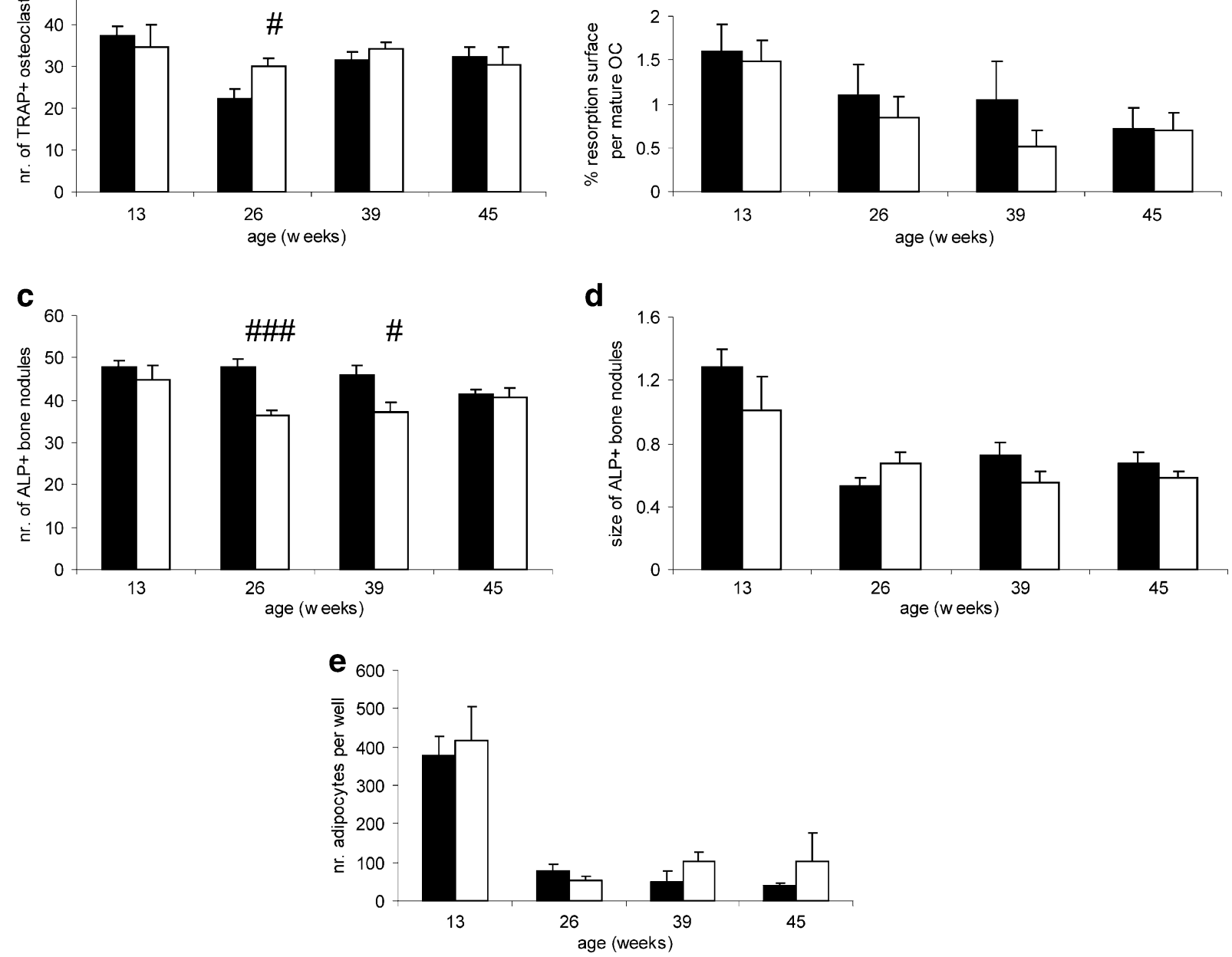

Fig. 5 Stem cell cultures of wild-type and TTD mice. Analyses of osteoclast, osteoblast and adipocyte differentiation capacity in bone marrow cell cultures in wild-type (solid bars) and TTD mice (open bars). Number of TRAP-positive osteoclasts (a), resorption surface per mature osteoclast $(\mathbf{b})$, number of alkaline phosphatase-positive bone nodules (c), size of alkaline phosphatase-positive bone nodules (d) and number of adipocytes (e). TTD mice compared to wild-type animals: ${ }^{*} p<0.05$, \#\#\# $p$ 0.001; error bars represent SEM 
declined resulting in similar numbers as in 45-week-old TTD mice (Fig. 5c). There was no significant difference in bone nodule size between wild-type and TTD mice at any age (Fig. 5d). Both wild-type and TTD nodules mineralized, but no significant differences between the genotypes could be detected at any age (data not shown). Similarly, both wild-type and TTD mice were able to form adipocytes but no significant differences between the genotypes could be detected at any age (Fig. 5e).

\section{PTH treatment}

Albeit with an accelerated decrease in bone nodule formation, the bone marrow cultures of TTD mice retained their capacity to generate osteoblasts and form bone. To investigate whether this bone forming capacity is still present and can be stimulated in vivo as well, we analyzed the effect of intermittent PTH treatment on bone structure in TTD mice. PTH treatment was started at 45 weeks of age, i.e., after the accelerated bone loss has started. Cortical bone volume showed an increase after 20 weeks intermittent PTH treatment as can be seen from the right shift in the 3D-thickness distribution (Fig. 6c). PTH treatment significantly increased trabecular bone volume fraction, trabecular thickness as well as cortical thickness suggesting that osteoblasts in TTD mice can still be stimulated to increase bone formation (Fig. 6a, b and d).

Fig. 6 PTH treatment in TTD mice. a Trabecular bone volume fraction $(\mathrm{BV} /$ TV), b trabecular thickness, c cortical thickness distribution and $\mathbf{d}$ cortical thickness in femora from PTH treated $(P T H)$ and control $(V E H)$ TTD mice. ${ }^{*} p<0.05$, $* * p<0.01$; error bars represent SEM

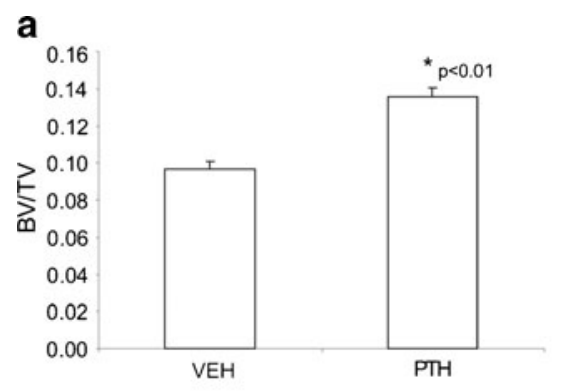

TTD mice display features of premature aging in many organs and tissues (de Boer et al. 2002; Wijnhoven et al. 2005), but the progeroid symptoms do not affect all tissues to the same extent. In fact, paradoxically, a detailed, systematic large cohort analysis revealed that some organs and tissues even exhibit features resembling caloric restriction and delayed aging. For instance, the occurrence of cataract in the eyes in TTD mice was found to be significantly less compared to the isogenic wild-type control mice kept under the same conditions (Wijnhoven et al. 2005). This extends the notion that all human progeroid syndromes are segmental (Martin 2005), i.e., that multiple organs suffer from rapid aging, yet others seem relatively unaffected and as shown by TTD mice may even age slower than wild-type controls. Microarray expression analysis of various accelerated aging mice revealed a strong parallel with expression profiles of normal aging (Niedernhofer et al. 2006; van der Pluijm et al. 2007). To examine at the level of physiology, whether TTD mice are indeed a bona fide model for aging and to rule out that it is a developmental disorder, we examined in great detail the effect of aging on bone parameters of female wild-type mice as well as progeroid TTD mice. The systematic analysis uncovered the consequence of a defect in DNA repair and basal transcription on the velocity of age-related skeletal

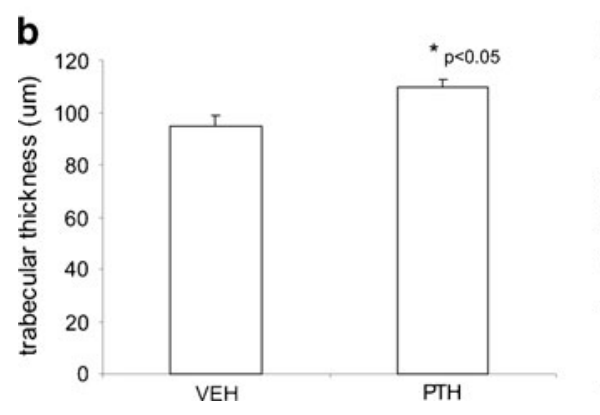

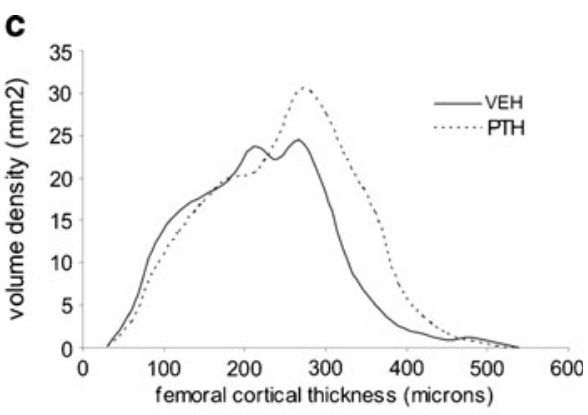

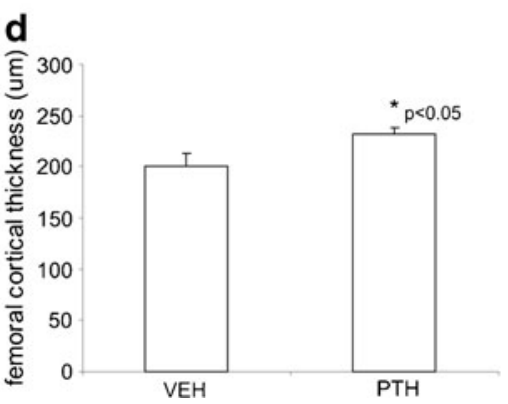


changes and assessed to which extent the skeletal abnormalities reflect normal bone aging.

Normal skeletal development but accelerated skeletal aging in progeroid TTD mice

It should be emphasized that by all parameters measured bone develops normally in TTD female mice, i.e., bone volume, cortical thickness and perimeter are similar in wild-type and TTD mice up to 39 weeks of age. In addition, similar numbers of osteoblasts and osteoclasts in bone marrow cultures as well as periosteal apposition are present up to at least 13 weeks of age. This observation excludes a developmental defect as explanation for the TTD phenotype and is in line with other studies on TTD mice (Wijnhoven et al. 2005).

After 39 weeks of age profound accelerated decrease in bone volume is observed in TTD mice. The decrease in bone volume and cortical thickness in TTD mice is almost 40 weeks ahead of that in wild-type mice. This accelerated form of natural bone aging strongly underlines the premature aging phenotype of TTD mice.

Notably, the decrease in bone volume is paralleled by an accelerated decrease in bone strength in TTD mice after 26 weeks of age, i.e., an ultimate fracture load as observed in 52-week-old TTD mice was only noticed in 104-week-old wild-type mice (Fig. 4b). An important mechanism underlying the accelerated decrease in bone strength is that in TTD mice the larger endocortical volume is not compensated by an increase in age-related periosteal apposition and perimeter as seen in wild-type mice. The accelerated decrease in bone strength cannot be explained by a change in mineralization grade of the matrix as assessed by quantitative backscatter scanning electron microscopy analyses or increased bone resorption as assessed by measurement of serum TRAP.

Lack of periosteal apposition as a cause of decreased bone strength in TTD mice

The lack of effective periosteal apposition in TTD mice is intriguing as it is a localized phenomenon. Despite the important role of periosteal apposition in establishing structural strength during growth and in maintaining strength during aging, little is known about the mechanism and control of periosteal apposition (Seeman 2003b). Currently, it is tempting to speculate that, with aging, increased bending stress on the outer surface of bone (due to endosteal bone loss and subsequent cortical thinning) leads to the stimulation of periosteal bone apposition (Akhter et al. 2002; Beck et al. 2001; Lazenby 1990). The force of mechanical bending and torsion varies linearly with the distance from the neutral axis and therefore bending stress is larger on the periosteal side of the bone (Currey 1999). Mechanical loading could thus influence periosteal apposition and a change in mechanical loading could consequently affect this process. In wild-type mice, we see the natural link between thinning of the cortex, increase in endocortical volume, the presence of periosteal apposition and increase in perimeter. In TTD mice this increase in perimeter is absent. As TTD mice, in contrast to wildtype mice do not accumulate fat with aging, the difference in weight (Wijnhoven et al. 2005) might contribute to the difference in periosteal apposition. However, we could not detect an obvious correlation between body weight and perimeter (unpublished observations). Moreover, in mice a relationship between body weight and femur, vertebral and phalangeal bone parameters has not been found (Beamer et al. 1996). TTD mice may provide an excellent tool to study periosteal apposition and to unravel the underlying mechanisms.

DNA repair defect and bone marrow stem cells in TTD mice

With regard to the accelerated decrease in bone formation and bone mass, the deficiency of DNA damage repair is very likely to have a causative effect. DNA lesions (e.g., induced by free radicals), which are a by-product of normal metabolism, are incompletely repaired by DNA-repair deficient TTD mice (de Boer et al. 2002). The increased damage load will lead to dysfunctional senescent cells or will cause apoptosis (Campisi 2005). Indeed, TTD mice appear to exhibit a decreased spontaneous tumor formation rate likely at least in part by an increased rate of apoptosis (de Boer and Hoeijmakers 1999; Wijnhoven et al. 2005), which protects from cancer but at the same time likely accelerates aging. An increased rate of apoptosis can therefore be expected to cause accelerated depletion of stem cells or early progenitor cells leading to a disturbed osteoblasts and adipocyte differentiation from mesenchymal stem cells and 
osteoclasts derived from the hematopoietic stem cell lineage. A decrease in mesenchymal stem cell number or disturbed differentiation is suggested by the fact that TTD mice lack abdominal fat mass (Compe et al. 2005). As the structural differences in bone became apparent after 39 weeks we analyzed bone marrow mesenchymal and hematopoietic stem cell differentiation in the period around this age starting at 13 weeks of age. Osteogenic analyses of the bone marrow cultures demonstrated an accelerated decrease in bone nodule formation implicating an accelerated reduction in the number of mesenchymal stem cells that can differentiate into osteoblasts that precedes the decrease in bone mass. The absence of differences in size of the bone nodules shows that the proliferative capacity of the stem cells present is not changed in TTD mice. Histomorphometric analyses showed that the number of osteoblasts in vivo was lower in tibia of TTD mice throughout life. These data suggest that DNA damage levels in TTD mice reach a critical threshold in (mesenchymal) stem cells between 13 and 26 weeks, which translates into reduced numbers of differentiated osteoblasts and a bone phenotype. Although we only studied bone marrow cultures up to 45 weeks, bone nodule formation in wild-type mice seems to decrease starting at 45 weeks of age, which is in line with the observed significant decrease in the number of osteoblasts in wild-type tibiae at 52 weeks of age. It was shown previously that old mice had significantly fewer stem cells with osteogenic potential than young animals (Bergman et al. 1996; Moerman et al. 2004). In humans, the number of stem cells with osteogenic potential was shown to decrease already at young age (D'Ippolito et al. 1999; Nishida et al. 1999; Zhou et al. 2008). Only at 26 weeks of age a drop in the number of osteoclasts observed in wildtype mice leads to a significant difference in in vitro osteoclast formation between wild-type and TTD mice while no significant differences in resorption capacity were observed. The decreased osteoblast differentiation at 26 weeks of age may explain the decrease in bone volume and structure as first observed after 39 weeks. Obviously, definite proof that the observed accelerated decrease in mesenchymal stem cells in TTD mice is due to accumulation of DNA damage as a consequence of deficient DNA repair is lacking and, with current technology, very difficult to obtain. However, the most plausible scenario is that loss of DNA repair indeed leads to accumulation of otherwise repaired DNA lesions, which triggers cell death and cellular senes- cence. In the case of bone metabolism, this results in an accelerated decrease in mesenchymal stem cells, suppression of growth and differentiation, deranged bone metabolism and inevitably premature loss of bone strength. Although there is an accelerated decrease in bone nodule formation, the current data show that TTD bone marrow mesenchymal stem cells retain bone forming capacity. This is further substantiated by the in vivo intermittent PTH treatment studies. Intermittent PTH administration to TTD mice demonstrated an increase in cortical thickness implicating that the stem cells/osteoblasts can still be stimulated to form bone. Considering the above-mentioned relationship between DNA repair and apoptosis, it is interesting to note that PTH has been reported to inhibit osteoblast apoptosis (Jilka et al. 1999; Sowa et al. 2003). The PTH effect on cortical thickness in TTD mice appears to be the result of increased endosteal bone formation and not periosteal apposition, as perimeter was not significantly changed. Interestingly, a recent study showed differences in mechanism by which intermittent PTH treatment increases bone formation at the endosteal and at the periosteal surface (Jilka et al. 2009). The increase in endocortical osteoblasts after intermittent PTH treatment is predominantly due to attenuated osteoblast apoptosis (Jilka et al. 2009). In periosteal bone where the rate of osteoblast apoptosis is low, PTH does not increase the number of osteoblasts by attenuating apoptosis, but by exerting pro-differentiating and/or pro-survival effects on postmitotic pre-osteoblasts (Jilka et al. 2009). These data are suggestive for different age-related mechanisms at the endosteal and periosteal level and in line with our hypothesis that increased apoptosis of osteoprogenitors contributes to the decreased periosteal apposition in TTD mice. The adipocyte cultures support the fact that the intrinsic differentiation capacity of mesenchymal stem cells is not affected. In vivo TTD mice lack fat accumulation, but in vitro normal adipocyte differentiation is observed. Overall, these observations point to an altered systemic environment in TTD mice. Currently, it should be concluded that the observed accelerated skeletal aging observed in TTD mice is the result from a combination of an accelerated decline in the number of osteogenic stem cells together with altered systemic influences.

In conclusion, we demonstrate that the increased and accelerated decrease in bone mass in DNA repairdeficient TTD mice is a premature aging feature, 
which implies that the other aging-like features in TTD mice and patients may also represent bona fide premature aging symptoms and which in a broader context substantiates the importance of DNA repair in healthy aging. The TTD mouse mutant constitutes a valid model for bone aging and the absence of periosteal apposition provides for identification of new targets for maintaining bone strength with aging.

Acknowledgements This research was supported in part by the Netherlands Organization for Scientific Research (NWO) through the foundation of the Research Institute Diseases of the Elderly, as well as grants from NIH (1PO1 AG17242-02), NIEHS (1UO1 ES011044), EC (QRTL-1999-02002), the Dutch Cancer Society (EUR 99-2004) and the European Commission (EU-LSHG-CT-2007-036894 'LifeSpan').

Open Access This article is distributed under the terms of the Creative Commons Attribution Noncommercial License which permits any noncommercial use, distribution, and reproduction in any medium, provided the original author(s) and source are credited.

\section{References}

Akhter MP, Cullen DM, Recker RR (2002) Bone adaptation response to sham and bending stimuli in mice. J Clin Densitom 5:207-216

Ambrogini E, Almeida M, Martin-Millan M, Paik JH, Depinho RA, Han L, Goellner J, Weinstein RS, Jilka RL, O'Brien CA et al (2010) FoxO-mediated defense against oxidative stress in osteoblasts is indispensable for skeletal homeostasis in mice. Cell Metab 11:36-146

Amling M, Priemel M, Holzmann T, Chapin K, Rueger JM, Baron R, Demay MB (1999) Rescue of the skeletal phenotype of vitamin D receptor-ablated mice in the setting of normal mineral ion homeostasis: formal histomorphometric and biomechanical analyses. Endocrinology 140:4982-4987

Andressoo JO, Hoeijmakers JH (2005) Transcription-coupled repair and premature ageing. Mutat Res 577:179-194

Beamer WG, Donahue LR, Rosen CJ, Baylink DJ (1996) Genetic variability in adult bone density among inbred strains of mice. Bone 18:397-403

Beck TJ, Stone KL, Oreskovic TL, Hochberg MC, Nevitt MC, Genant HK, Cummings SR (2001) Effects of current and discontinued estrogen replacement therapy on hip structural geometry: the study of osteoporotic fractures. J Bone Miner Res 16:2103-2110

Bergman RJ, Gazit D, Kahn AJ, Gruber H, McDougall S, Hahn TJ (1996) Age-related changes in osteogenic stem cells in mice. J Bone Miner Res 11:568-577

Bootsma D, Kraemer KH, Cleaver JE, Hoeijmakers JHJ (1998) Nucleotide excision repair syndromes: xeroderma pigmentosum, Cockayne syndrome and trichothiodystrophy. In: Vogelstein B, Kinzler KW (eds) The genetic basis of human cancer. McGraw-Hill, New York, pp 245-274
Botta E, Nardo T, Broughton BC, Marinoni S, Lehmann AR, Stefanini M (1998) Analysis of mutations in the XPD gene in Italian patients with trichothiodystrophy: site of mutation correlates with repair deficiency, but gene dosage appears to determine clinical severity. Am J Hum Genet 63:1036-1048

Broderick E, Infanger S, Turner TM, Sumner DR (2005) Depressed bone mineralization following high dose TGFbetal application in an orthopedic implant model. Calcif Tissue Int 76:379-384

Campisi J (2005) Senescent cells, tumor suppression, and organismal aging: good citizens, bad neighbors. Cell 120:513-522

Chalut C, Moncollin V, Egly JM (1994) Transcription by RNA polymerase II: a process linked to DNA repair. BioEssays 16:651-655

Chan GK, Duque G (2002) Age-related bone loss: old bone, new facts. Gerontology 48:62-71

Chapman S (1988) The trichothiodystrophy syndrome of Pollitt. Pediatr Radiol 18:154-156

Civitelli R, McAlister WH, Teitelbaum SL, Whyte MP (1989) Central osteosclerosis with ectodermal dysplasia: clinical, laboratory, radiologic, and histopathologic characterization with review of the literature. J Bone Miner Res 4:863-875

Compe E, Drane P, Laurent C, Diderich K, Braun C, Hoeijmakers JH, Egly JM (2005) Dysregulation of the peroxisome proliferator-activated receptor target genes by XPD mutations. Mol Cell Biol 25:6065-6076

Currey JD (1999) What determines the bending strength of compact bone? J Exp Biol 202:2495-2503

de Boer J, Hoeijmakers JH (1999) Cancer from the outside, aging from the inside: mouse models to study the consequences of defective nucleotide excision repair. Biochimie 81:127-137

de Boer J, de Wit J, van Steeg H, Berg RJ, Morreau H, Visser P, Lehmann AR, Duran M, Hoeijmakers JH, Weeda G (1998) A mouse model for the basal transcription/DNA repair syndrome trichothiodystrophy. Mol Cell 1:981-990

de Boer J, Andressoo JO, de Wit J, Huijmans J, Beems RB, van Steeg H, Weeda G, van der Horst GT, van Leeuwen W, Themmen AP et al (2002) Premature aging in mice deficient in DNA repair and transcription. Science 296:1276-1279

D'Ippolito G, Schiller PC, Ricordi C, Roos BA, Howard GA (1999) Age-related osteogenic potential of mesenchymal stromal stem cells from human vertebral bone marrow. J Bone Miner Res 14:1115-1122

Faghri S, Tamura D, Kraemer KH, Digiovanna JJ (2008) Trichothiodystrophy: a systematic review of 112 published cases characterises a wide spectrum of clinical manifestations. J Med Genet 45:609-621

Giglia-Mari G, Coin F, Ranish JA, Hoogstraten D, Theil A, Wijgers N, Jaspers NG, Raams A, Argentini M, van der Spek PJ et al (2004) A new, tenth subunit of TFIIH is responsible for the DNA repair syndrome trichothiodystrophy group A. Nat Genet 36:714-719

Gillet LC, Scharer OD (2006) Molecular mechanisms of mammalian global genome nucleotide excision repair. Chem Rev 106:253-276

Glatt V, Canalis E, Stadmeyer L, Bouxsein ML (2007) Age-related changes in trabecular architecture differ in female and male C57BL/6J mice. J Bone Miner Res 22:1197-1207

Hanawalt PC (2002) Subpathways of nucleotide excision repair and their regulation. Oncogene 21:8949-8956 
Harada S, Rodan GA (2003) Control of osteoblast function and regulation of bone mass. Nature 423:349-355

Hashimoto S, Egly JM (2009) Trichothiodystrophy view from the molecular basis of DNA repair/transcription factor TFIIH. Hum Mol Genet 18:R224-R230

Hildebrand T, Laib A, Muller R, Dequeker J, Ruegsegger P (1999) Direct three-dimensional morphometric analysis of human cancellous bone: microstructural data from spine, femur, iliac crest, and calcaneus. J Bone Miner Res 14:1167-1174

Hoeijmakers JH (2001) Genome maintenance mechanisms for preventing cancer. Nature 411:366-374

Hoeijmakers JH, Egly JM, Vermeulen W (1996) TFIIH: a key component in multiple DNA transactions. Curr Opin Genet Dev 6:26-33

Hwang JR, Moncollin V, Vermeulen W, Seroz T, van Vuuren H, Hoeijmakers JH, Egly JM (1996) A 3' - > 5' XPB helicase defect in repair/transcription factor TFIIH of xeroderma pigmentosum group $\mathrm{B}$ affects both DNA repair and transcription. J Biol Chem 271:15898-15904

Itin PH, Sarasin A, Pittelkow MR (2001) Trichothiodystrophy: update on the sulfur-deficient brittle hair syndromes. J Am Acad Dermatol 44:891-920, quiz 921-894

Jilka RL, Weinstein RS, Bellido T, Roberson P, Parfitt AM, Manolagas SC (1999) Increased bone formation by prevention of osteoblast apoptosis with parathyroid hormone. J Clin Invest 104:439-446

Jilka RL, O'Brien CA, Ali AA, Roberson PK, Weinstein RS, Manolagas SC (2009) Intermittent PTH stimulates periosteal bone formation by actions on post-mitotic preosteoblasts. Bone 44:275-286

Kawaguchi H, Manabe N, Miyaura C, Chikuda H, Nakamura K, Kuro-o M (1999) Independent impairment of osteoblast and osteoclast differentiation in klotho mouse exhibiting low-turnover osteopenia. J Clin Invest 104:229-237

Kousseff BG, Esterly NB (1988) Trichothiodystrophy, IBIDS syndrome or Tay syndrome? Birth Defects Orig Artic Ser 24:169-181

Lazenby RA (1990) Continuing periosteal apposition: II. The significance of peak bone mass, strain equilibrium, and age-related activity differentials for mechanical compensation in human tubular bones. Am J Phys Anthropol $82: 473-484$

Leupold D (1979) Ichthyosis congenita, cataract, mental retardation, ataxia, osteosclerosis and immunologic deficiency - a particular syndrome? Monatsschr Kinderheilkd 127:307-308

Manolagas SC (2010) From estrogen-centric to aging and oxidative stress: a revised perspective of the pathogenesis of osteoporosis. Endocrine Rev

Martin GM (2005) Genetic modulation of senescent phenotypes in Homo sapiens. Cell 120:523-532

McCuaig C, Marcoux D, Rasmussen JE, Werner MM, Gentner NE (1993) Trichothiodystrophy associated with photosensitivity, gonadal failure, and striking osteosclerosis. J Am Acad Dermatol 28:820-826

Moerman EJ, Teng K, Lipschitz DA, Lecka-Czernik B (2004) Aging activates adipogenic and suppresses osteogenic programs in mesenchymal marrow stroma/stem cells: the role of PPAR-gamma2 transcription factor and TGF-beta/ BMP signaling pathways. Aging Cell 3:379-389
Niedernhofer LJ, Garinis GA, Raams A, Lalai AS, Robinson AR, Appeldoorn E, Odijk H, Oostendorp R, Ahmad A, van Leeuwen $\mathrm{W}$ et al (2006) A new progeroid syndrome reveals that genotoxic stress suppresses the somatotroph axis. Nature 444:1038-1043

Nishida S, Endo N, Yamagiwa H, Tanizawa T, Takahashi HE (1999) Number of osteoprogenitor cells in human bone marrow markedly decreases after skeletal maturation. J Bone Miner Metab 17:171-177

Parfitt AM, Drezner MK, Glorieux FH, Kanis JA, Malluche H, Meunier PJ, Ott SM, Recker RR (1987) Bone histomorphometry: standardization of nomenclature, symbols, and units. Report of the ASBMR Histomorphometry Nomenclature Committee. J Bone Miner Res 2:595-610

Price VH, Odom RB, Ward WH, Jones FT (1980) Trichothiodystrophy: sulfur-deficient brittle hair as a marker for a neuroectodermal symptom complex. Arch Dermatol 116:1375-1384

Przedborski S, Ferster A, Goldman S, Wolter R, Song M, Tonnesen T, Pollitt RJ, Vamos E (1990) Trichothiodystrophy, mental retardation, short stature, ataxia, and gonadal dysfunction in three Moroccan siblings. Am J Med Genet 35:566-573

Rached MT, Kode A, Xu L, Yoshikawa Y, Paik JH, Depinho RA, Kousteni S (2010) FoxO1 is a positive regulator of bone formation by favoring protein synthesis and resistance to oxidative stress in osteoblasts. Cell Metab 11:147-160

Riggs BL, Khosla S, Melton LJ 3rd (2002) Sex steroids and the construction and conservation of the adult skeleton. Endocrine Rev 23:279-302

Roschger P, Fratzl P, Eschberger J, Klaushofer K (1998) Validation of quantitative backscattered electron imaging for the measurement of mineral density distribution in human bone biopsies. Bone 23:319-326

Russo CR, Lauretani F, Seeman E, Bartali B, Bandinelli S, Di Iorio A, Guralnik J, Ferrucci L (2006) Structural adaptations to bone loss in aging men and women. Bone 38:112-118

Seeman E (2001) During aging, men lose less bone than women because they gain more periosteal bone, not because they resorb less endosteal bone. Calcif Tissue Int 69:205-208

Seeman E (2002) Pathogenesis of bone fragility in women and men. Lancet 359:1841-1850

Seeman E (2003a) Invited review: pathogenesis of osteoporosis. J Appl Physiol 95:2142-2151

Seeman E (2003b) Periosteal bone formation - a neglected determinant of bone strength. New Engl J Med 349:320 323

Seroz T, Hwang JR, Moncollin V, Egly JM (1995) TFIIH: a link between transcription, DNA repair and cell cycle regulation. Curr Opin Genet Dev 5:217-221

Sowa H, Kaji H, Iu MF, Tsukamoto T, Sugimoto T, Chihara K (2003) Parathyroid hormone-Smad3 axis exerts antiapoptotic action and augments anabolic action of transforming growth factor beta in osteoblasts. J Biol Chem 278:52240-52252

Sugasawa K (2010) Regulation of damage recognition in mammalian global genomic nucleotide excision repair. Mutat Res 685:29-37 
Svejstrup JQ, Vichi P, Egly JM (1996) The multiple roles of transcription/repair factor TFIIH. Trends Biochem Sci 21:346-350

Toelle SP, Valsangiacomo E, Boltshauser E (2001) Trichothiodystrophy with severe cardiac and neurological involvement in two sisters. Eur J Pediatr 160:728-731

van der Eerden BC, Hoenderop JG, de Vries TJ, Schoenmaker T, Buurman CJ, Uitterlinden AG, Pols HA, Bindels RJ, van Leeuwen JP (2005) The epithelial $\mathrm{Ca}^{2+}$ channel TRPV5 is essential for proper osteoclastic bone resorption. Proc Natl Acad Sci U S A 102:17507-17512

van der Pluijm I, Garinis GA, Brandt RM, Gorgels TG, Wijnhoven SW, Diderich KE, de Wit J, Mitchell JR, van Oostrom C, Beems R et al (2007) Impaired genome maintenance suppresses the growth hormone-insulin-like growth factor 1 axis in mice with Cockayne syndrome. PLoS Biol 5:e2
Waarsing JH, Day JS, Weinans H (2004) An improved segmentation method for in vivo microCT imaging. $\mathrm{J}$ Bone Miner Res 19:1640-1650

Wakeling EL, Cruwys M, Suri M, Brady AF, Aylett SE, Hall C (2004) Central osteosclerosis with trichothiodystrophy. Pediatr Radiol 34:541-546

Wijnhoven SW, Beems RB, Roodbergen M, van den Berg J, Lohman PH, Diderich K, van der Horst GT, Vijg J, Hoeijmakers JH, van Steeg H (2005) Accelerated aging pathology in ad libitum fed Xpd(TTD) mice is accompanied by features suggestive of caloric restriction. DNA Repair (Amst)

Zhou S, Greenberger JS, Epperly MW, Goff JP, Adler C, Leboff MS, Glowacki J (2008) Age-related intrinsic changes in human bone-marrow-derived mesenchymal stem cells and their differentiation to osteoblasts. Aging Cell 7:335-343 